\title{
DEFLECTION OF LAPPED CONNECTED Z COLD FORMED PURLINS*
}

\author{
Ishac. I. Ishac, Osama M. Elhussieny, and Reda M. Ghamry ${ }^{+}$ \\ Steel Structures Eng. Dept., Faculty of Engineering, Zagazig University, Zagazig, Egypt
}

\begin{abstract}
Cold-formed steel $\mathrm{Z}$ sections are widely used in modern roof systems as purlins . To maintain their continuity, these sections might be overlapped over their interior supports. The overlapping operation introduces cross-sectional changes which would affect the structural behavior of the purlins upon loading. In this study, many parameters that affect the structural behavior of $\mathrm{Z}$ purlins are introduced. The finite element technique was used to simulate the structural behavior of lapped connections over the internal supports in multi span cold-formed stiffened steel $\mathrm{Z}$ purlin systems. The considered beams had span lengths of 500,600,700 and $800 \mathrm{~cm}$ with nominal web depths of 20.0 $\mathrm{cm}$. and thickness $2.0 \mathrm{~mm}$. The work program includes modeling of a single $\mathrm{Z}$ section beam with lap lengths $50,100,125,150$ and $175 \mathrm{~cm}$. The considered lap models for connected ends lap joint using web bolts at the lap ends plus self-drilling screws at the top flange. The case of simply supported $\mathrm{Z}$ purlins is also considered in the work for comparison. Based on this analysis using the (ABAQUS 6.8) the deflections of lapped beams of stiffened $\mathrm{Z}$ sections are studied and presented. Empirical equations were obtained to predict the deflection of bolted end lapped purlin. The results based on these equations were compared with the experimental results and good agreement is achieved.
\end{abstract}

KEYWORDS: Lapped Connection, Cold Formed Section, Bolted End, Purlin.

\section{DETOURNEMENTS DE FROID RODEE CONNECTÉ Z PANNES FORMÉ}

\section{RÉSUMÉ}

Formé à froid en acier Profilés en $\mathrm{Z}$ sont largement utilisés dans les systèmes de toit moderne comme pannes. Afin de maintenir leur continuité, ces sections peuvent être imbriquées sur leurs supports intérieurs. L'opération qui se chevauchent introduit transversale des changements qui affectent le comportement structurel des pannes lors du chargement. Dans cette étude, de nombreux paramètres qui influent sur le comportement structurel des pannes $\mathrm{Z}$ sont introduits. La technique des éléments finis a été utilisée pour simuler le comportement structural des connexions rodée sur les supports internes de la durée de multi formé à froid raidi acier $\mathrm{Z}$ systèmes pannes. Les poutres considérées avaient des longueurs des travées 500600700 et $800 \mathrm{~cm}$ avec une profondeur nominale de Web 20,0 cm. et l'épaisseur de 2,0 $\mathrm{mm}$. Le programme de travail inclut la modélisation d'un faisceau de $\mathrm{Z}$ seule section avec 50100125150 longueurs genoux et $175 \mathrm{~cm}$. Les modèles genoux en considération pour les extrémités sont reliées au tour joint à l'aide des boulons Web à tour se termine ainsi vis auto-perceuses à la bride supérieure. Le cas de pannes simplement appuyée $\mathrm{Z}$ est également pris en compte dans le travail de comparaison. Basé sur cette analyse en utilisant l'(ABAQUS 6.8) les flexions des poutres de sections rodées $\mathrm{Z}$ raidis sont étudiés et présentés. Équations empiriques ont été obtenus pour prédire la déviation de la fin boulonné rodée pannes. Les résultats basés sur ces équations ont été comparés avec les résultats expérimentaux et un bon accord est obtenu.

Mots-clés: connexion patte, Cold section formée, Fin boulonné, pannes.
* $\quad$ Received: 8/6/2011, Accepted: 5/7/2011 (Original Paper)
+ Contact Author (+20 119733008) 
DEFLECTION OF LAPPED CONNECTED Z COLD FORMED PURLINS

Ishac, Elhussieny and Ghamry

\section{INTRODUCTION}

Cold-formed steel purlins are widely used in modern roof systems due to their high structural efficiency and build ability. The most common shapes of cold-formed steel purlins are $\mathrm{C}$ and $\mathrm{Z}$ sections, and the section depth range is from 100 to $350 \mathrm{~mm}$ while the thickness range is from 1.2 to $3.0 \mathrm{~mm}$. Common yield strengths are 280 and 350 $\mathrm{N} / \mathrm{mm}^{2}$, but recently, sections with yield strength up to $450 \mathrm{~N} / \mathrm{mm}^{2}$ may be found in some purlin systems giving improved load carrying capacities. Ahmed Ali Ghosn [4] tested a stiffened Z-section beam purlins to evaluate the deflection behavior of lap joints under combined bending and shear. The results were obtained at failure load and the mode of failure for each test was illustrated. Twenty eight sets of specimens were tested where their dimensions and material properties are shown in Tables (1) and (2) and Fig (1) show the details of test setup

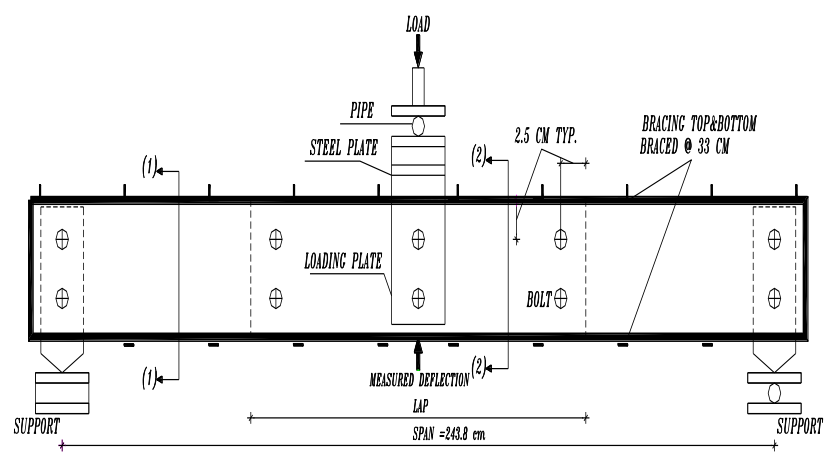

Fig (1) Details of test setup

\section{VERIFICATION BY FINITE ELEMENT MODEL}

Table (1): Test Parameters for Tested Beams [4].

\begin{tabular}{|c|c|c|c|}
\hline \hline Section $^{a}$ & $\begin{array}{c}\text { Web depth to } \\
\text { thickness, } \mathrm{h} / \mathrm{t}\end{array}$ & Lap length (cm) & Number of testes \\
\hline \hline Z 8X060 & 131 & $0^{b}, 61.0,121.9,243.8^{c}$ & 4 \\
\hline Z 9.5X075 & 125 & $0,61.0,91.4,121.9,152.4,243.8$ & 12 \\
\hline Z 8X075 & 105 & $0,61.0,121.9,243.8$ & 4 \\
\hline Z 9.5X101 & 92 & $0,61.0,121.9,243.8$ & 4 \\
\hline Z 8X099 & 79 & $0,61.0,121.9,243.8$ & 4 \\
\hline \hline
\end{tabular}

Where:

${ }^{a}$ Section is identified as: $\mathrm{Z}(\mathrm{h}) *(\mathrm{t})$; where " $\mathrm{h}$ " is the web depth in inches $(1$ in. $=25.4 \mathrm{~mm})$ and " $\mathrm{t}$ " is the thickness in thousandths of an inch. $b$

Single continuous $\mathrm{Z}$ section, no lap.

$c$

Full lap: double $\mathrm{Z}$ section over entire span.

Table (2): Cross-sectional and Mechanical Properties of Tested Beams [4].

\begin{tabular}{|c|c|c|c|c|c|c|}
\hline Section & $\mathbf{h} / \mathbf{t}$ & $\begin{array}{c}\mathbf{I} g \\
\left(\mathbf{c m}^{4}\right)^{a}\end{array}$ & $\begin{array}{c}\mathbf{I}_{e} \\
\left(\mathbf{c m}^{4}\right)^{b}\end{array}$ & $\begin{array}{c}\mathbf{S}_{e} \\
\left(\mathbf{c m}^{3}\right)^{c}\end{array}$ & $\begin{array}{c}\mathbf{F}_{y} \\
(\mathbf{M p a})^{d}\end{array}$ & $\begin{array}{c}\mathbf{F}_{u} \\
(\mathbf{M p a})^{e}\end{array}$ \\
\hline Z 8X060 & 131 & 344.2 & 314.3 & 29.17 & 418 & 529 \\
\hline Z 9.5X075 & 125 & 638.0 & 591.9 & 47.05 & 342 & 521 \\
\hline Z 8X075 & 105 & 425.0 & 392.5 & 36.87 & 342 & 521 \\
\hline Z9.5X101 & 92 & 854.9 & 854.9 & 70.79 & 421 & 531 \\
\hline Z 8X099 & 79 & 557.3 & 557.3 & 54.88 & 421 & 531 \\
\hline
\end{tabular}

Where:

${ }^{a}$ I $g=$ Gross moment of inertia.

$b$ I $e=$ Effective moment of inertia.

c $\mathrm{S} e=$ Effective section modulus.

${ }^{d} \mathrm{~F}_{y}=$ Yield strength.

$e$ $\mathrm{F}_{u}=$ Ultimate strength. 


\section{COMPARISON STUDY}

Four specimens of section Z8X060 (Single Z, Lap $61 \mathrm{~cm}$, Lap $121.9 \mathrm{~cm}$, Lap $243.8 \mathrm{~cm}$ ) with material properties mentioned before are modeled by Using F.E.M (ABAQUS V 6.8) [2] results are plotted together with the experimental data in Figs. (3), (4), (5) and (6).The graphs indicate that the FEM models are approximately agree with the experimental work for each specimen with acceptable accuracy. Theses figures show the relation between deflection and load, the deflection increase with load up to the failure of the beam. It is be noted that the deflections decrease with the increase of lap length. Fig.(2) show the deflection for lapped purlin with lap length $=61 \mathrm{~cm}$

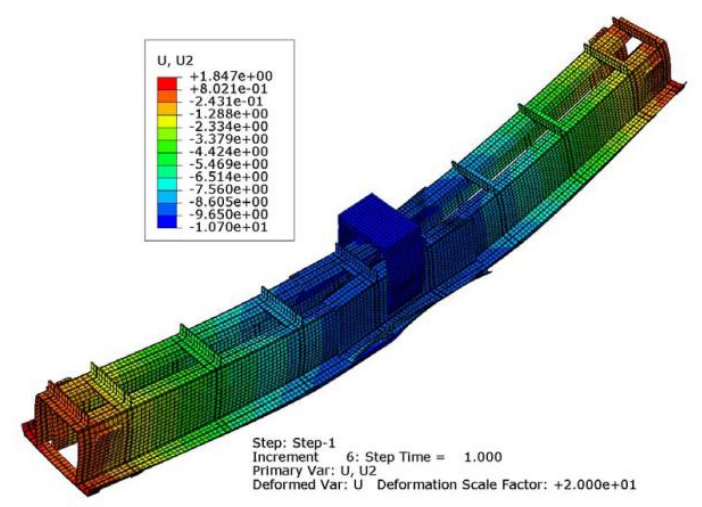

Fig.(2) Deflection for lap length=61cm

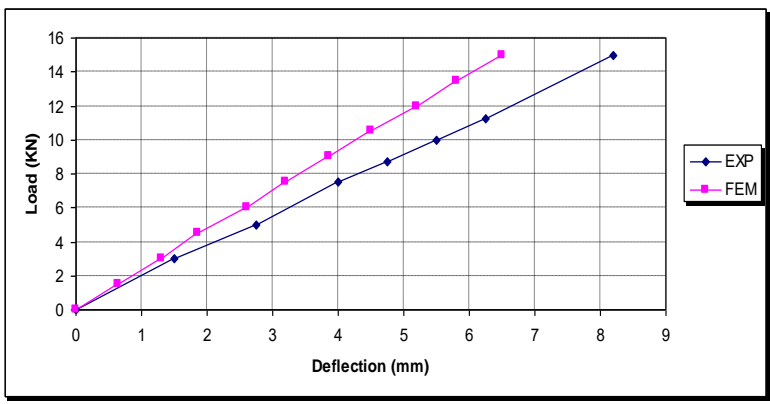

Fig.(3) Load- Deflection curve at mid-span for (single beam)

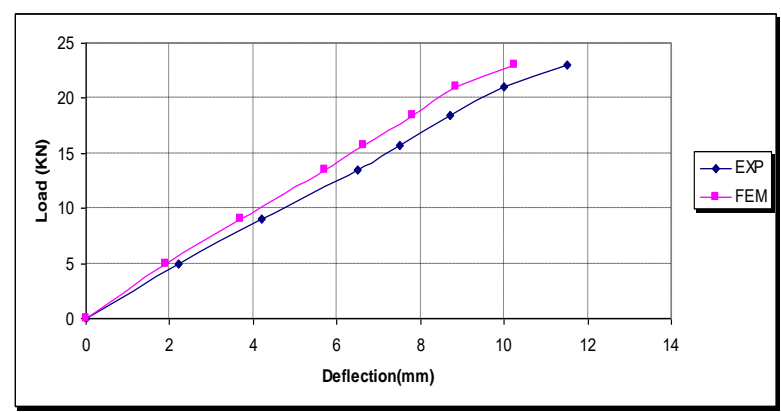

Fig. (4) Load- deflection curve at mid-span for (lap length $=61 \mathrm{~cm}$ )

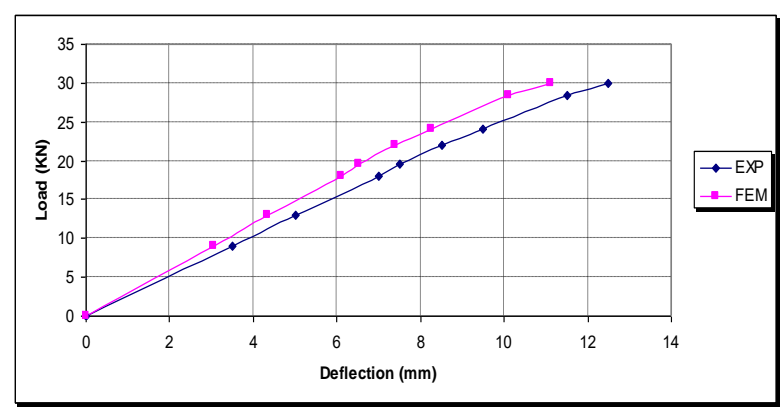

Fig. (5) Load- deflection curve at mid-span for (lap length $=121.9 \mathrm{~cm}$ )

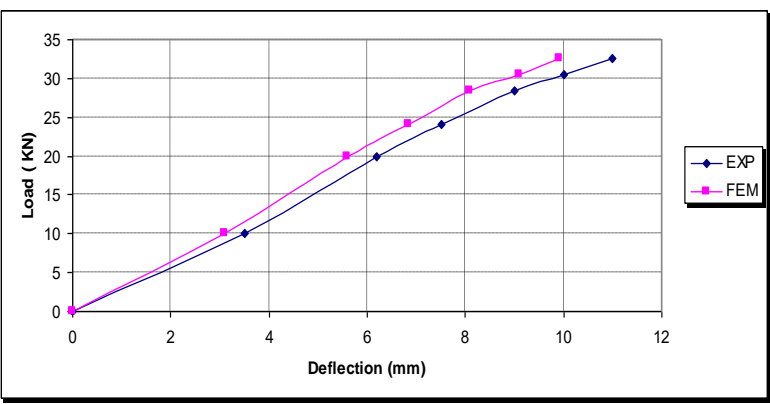

Fig. (6) Load- deflection curve at mid-span for (full lap=243.8cm)

Table (3): Values of maximum deflection vs. test results at mid-span.

\begin{tabular}{|c|c|c|c|}
\hline $\begin{array}{c}\text { Test } \\
\text { No. }\end{array}$ & $\begin{array}{c}\text { FEM } \\
\text { deflection } \\
(\mathrm{mm})\end{array}$ & $\begin{array}{c}\text { Lab. Test } \\
\text { deflection } \\
(\mathrm{mm})\end{array}$ & $\begin{array}{c}\text { FEM/Test } \\
\text { deflection } \\
\text { Ratio }\end{array}$ \\
\hline 1 & -7.52 & -8.2 & 0.917 \\
\hline 2 & -10.25 & -11.5 & 0.891 \\
\hline 3 & -11.12 & -12.5 & 0.889 \\
\hline 4 & 9.85 & -11 & 0.895 \\
\hline
\end{tabular}


Ishac, Elhussieny and Ghamry

A comparison of the FEM results with test results listed in table (3) indicates that the F.E method is an effective means to predict the deflection of $\mathrm{Z}$ purlin. Generally, there is a shift between experimental test and FEM deflection curve due to fixed simulation of the bolts in FEM where the bolts are simulate with tie constrain. Maximum deflection values are approximately equal.

\section{PARAMETRIC STUDY}

The corrugated sheets with thickness of 0.50 $\mathrm{mm}$ and width $1.0 \mathrm{~m}$ as shown in Fig.(7), give : $A=6.09 \mathrm{~cm}^{2}, \mathrm{Wt}=4.78 \mathrm{~kg} / \mathrm{m}^{2}$

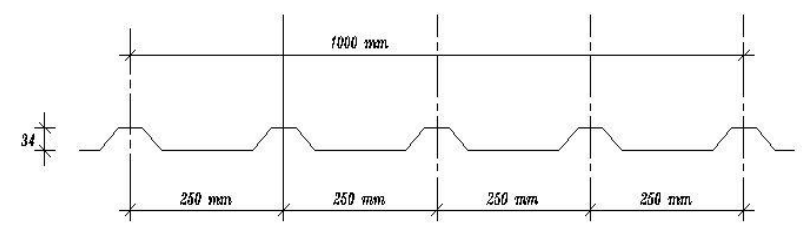

Fig.(7) The considered section of corrugated sheets

The considered section in this study is shown in Fig. (8) where, The purlin section is $200 \mathrm{Z} 20$ with properties: $\mathbf{I}_{X}=409.1 \mathrm{~cm}^{4}$,

$$
\begin{aligned}
& \text { I } y=57.30 \mathrm{~cm}^{4} . \quad \mathrm{A}=6.90 \mathrm{~cm}^{2}, \\
& \mathrm{~A}_{\text {eff }}=6.74 \mathrm{~cm}^{2} . \mathrm{Wt}=5.42 \mathrm{~kg} / \mathrm{m} .
\end{aligned}
$$

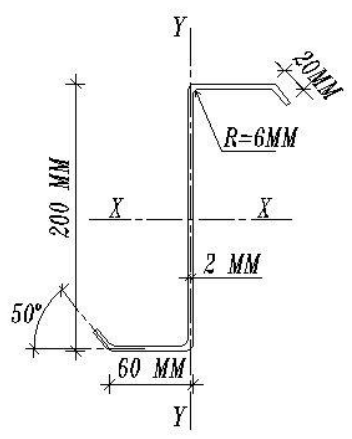

Fig. (8) The considered section of $\mathrm{z}$ purlin
The seat angle with dimensions $160 * 80 * 8 \mathrm{~mm}$ and length $=110 \mathrm{~mm}$. The spacing between the purlins equal to $150 \mathrm{~cm}$. The load considered in this work is uniform vertical load equal to $105 \mathrm{~kg} / \mathrm{m}$ - , which represent own weight of purlin, own weight of corrugated sheets and live load equal to $53.50 \mathrm{~kg} / \mathrm{m} 2$. The properties of steel that used in the study are,

$$
\begin{aligned}
\mathrm{E} & =200000 \mathrm{~N} / \mathrm{mm}^{2} \quad, \gamma=7800 \mathrm{~kg} / \mathrm{m}^{3}, \mathrm{f} \\
y & =360 \mathrm{~N} / \mathrm{mm}^{2}, \quad \mathrm{f}_{u}=520 \mathrm{~N} / \mathrm{mm}^{2}, \\
v & =0.30 \text { where: }
\end{aligned}
$$

$\mathrm{E}=$ Young's modulus, $\mathrm{N} / \mathrm{mm}^{2}, v=$ Poisson's ratio

$\gamma=$ unit weight, $\mathrm{kg} / \mathrm{m}^{3}$

$\mathrm{f}_{y}=$ steel yield stress, $\mathrm{N} / \mathrm{mm}^{2}$

$\mathrm{f}_{u}=$ steel ultimate stress, $\mathrm{N} / \mathrm{mm}^{2}$

\subsection{Deflection Analysis of Bolted End Lapped Sections}

The model considered consists of two $\mathrm{Z}$ sections spacing between them equals to $150 \mathrm{~cm}$ connected by corrugated sheets. One seat angle is used for each connection; purlins used are with variable lengths (L) 500,600,700 and $800 \mathrm{~cm}$ with variable lap length $\left(\mathrm{L}_{p}\right) 50,100,125,150$ and $175 \mathrm{~cm}$ for each length as shown in Fig. (9). 8 bolts of diameter $12 \mathrm{~mm}$ are used in the lap joint as shown in Fig.( 9) .The deflection is studied at centerline of the web of the purlin along the whole length.

Fig. (10) show deflection for $\left(\mathrm{L}_{p}=50 \mathrm{~cm}, \mathrm{~L}=500\right.$ $\mathrm{cm})$. 


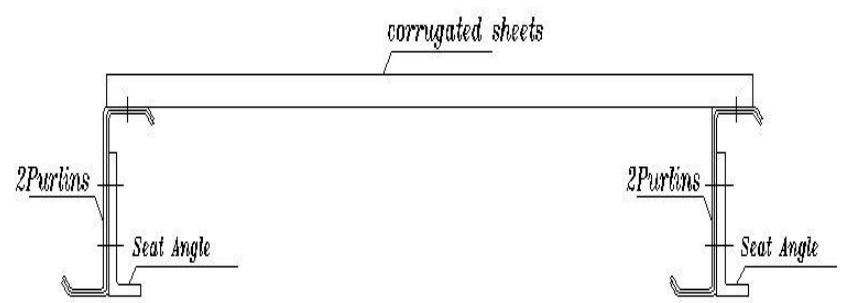

a) SEC (1-1)

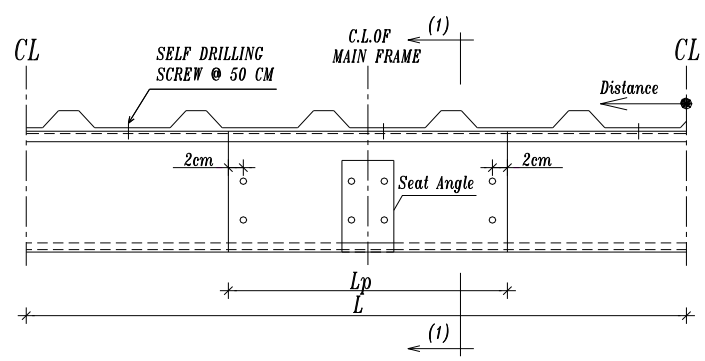

b) Elevation

Fig. (9) Bolted end lapped connection

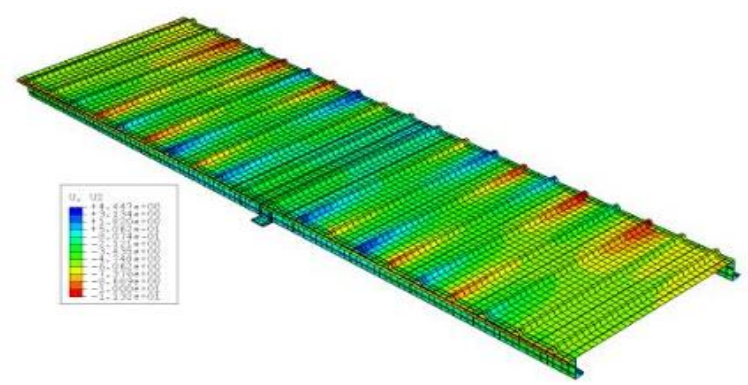

Fig. (10) Deflection for $\left(\mathrm{L}_{p}=50 \mathrm{~cm}, \mathrm{~L}=500 \mathrm{~cm}\right)$

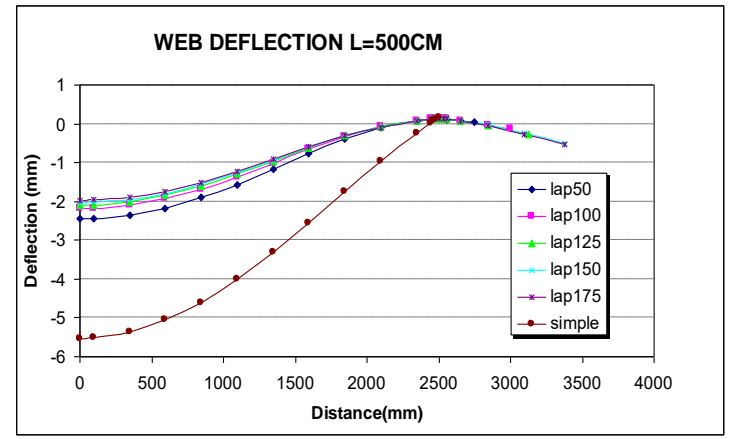

\section{Fig. (11) Deflection along centerline of web for span $500 \mathrm{~cm}$}

Fig (11) shows the relation between deflections versus the distance along web center line with different lengths of lap joints for span length equal to $500 \mathrm{~cm}$. The deflection increase from the seat angle to the maximum value at mid-span of purlin from $0.0 \mathrm{~mm}$ to $5.528 \mathrm{~mm}$ for simple purlin. The deflection decreases with the increase of lap length, where the maximum deflection is ranging between $2.453 \mathrm{~mm}$ to $1.967 \mathrm{~mm}$ for lap length ranging between 50 to $175 \mathrm{~cm}$ respectively. The ratio between the maximum deflection from lapped span with lap length $175 \mathrm{~cm}$ to the deflection of simple span equal to 0.354 . Table (4) shows the ratio between the deflections for variable lap lengths at maximum value to the maximum deflection value for the simple span. It is to be noted that the ratio given in this table is the ratio between the deflection of the lapped purlin to that of the simple purlin.

Table (4): Deflection at mid-span for span $500 \mathrm{~cm}$

\begin{tabular}{|c|c|c|}
\hline \multirow{2}{*}{$\begin{array}{c}\text { Lap length } \\
\end{array}$} & \multicolumn{2}{|c|}{ Deflection at mid span } \\
\cline { 2 - 3 } & Deflection(mm) & Ratio \\
\hline $\mathrm{L}_{P}=50$ & -2.453 & 0.444 \\
\hline $\mathrm{L}_{P}=100$ & -2.186 & 0.395 \\
\hline $\mathrm{L}_{P}=125$ & -2.091 & 0.378 \\
\hline $\mathrm{L}_{P}=150$ & -2.027 & 0.366 \\
\hline $\mathrm{L}_{P}=175$ & -1.967 & 0.354 \\
\hline Simple & -5.528 & 1 \\
\hline
\end{tabular}

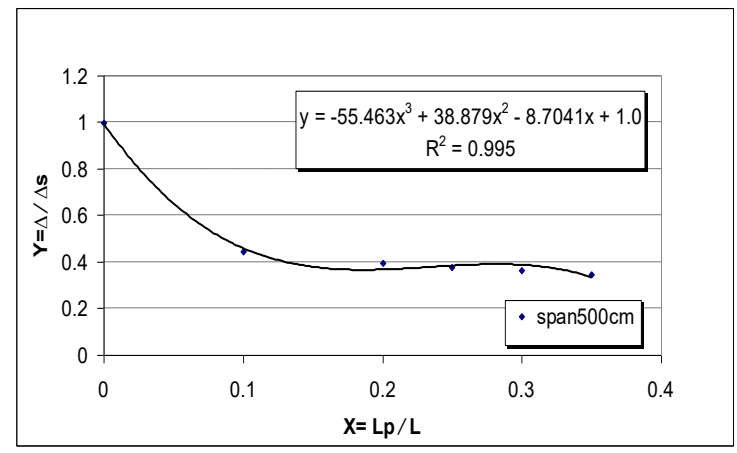

Fig . (12) Relation between $\Delta / \Delta \mathrm{s}$ and $\mathrm{l}_{p} / \mathrm{l}$ for span $500 \mathrm{~cm}$ 
DEFLECTION OF LAPPED CONNECTED Z COLD FORMED PURLINS

Ishac, Elhussieny and Ghamry

From Fig.(12) the following equation can be obtained.

$$
\begin{aligned}
\Delta / \Delta \mathrm{s}= & -55.463\left(\mathrm{~L}_{p} / \mathrm{L}\right)^{3}+38.879\left(\mathrm{~L}_{p} / \mathrm{L}\right)^{2} \\
& -8.704\left(\mathrm{~L}_{p} / \mathrm{L}\right)+1.0 \ldots \ldots \ldots \ldots \ldots
\end{aligned}
$$

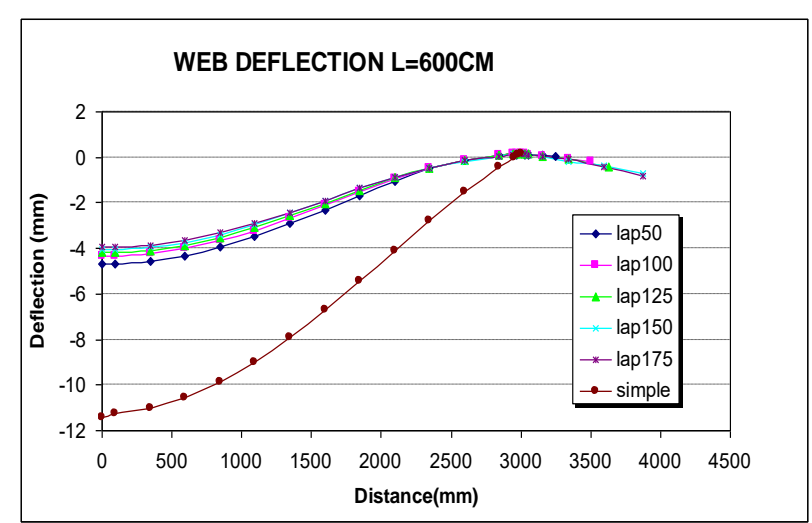

Fig • (13) Deflection along centerline of web for span $600 \mathrm{~cm}$

Table (5): Deflection at mid-span for span $600 \mathrm{~cm}$

\begin{tabular}{|c|c|c|}
\hline \multirow{2}{*}{$\begin{array}{c}\text { Lap length } \\
(\mathrm{cm})\end{array}$} & \multicolumn{2}{|c|}{ Deflection at mid span } \\
\cline { 2 - 3 } & Deflection(mm) & Ratio \\
\hline $\mathrm{L}_{P=50}$ & -4.771 & 0.413 \\
\hline $\mathrm{L}_{P=100}$ & -4.357 & 0.382 \\
\hline $\mathrm{L}_{P}=125$ & -4.191 & 0.367 \\
\hline $\mathrm{L}_{P=150}$ & -4.075 & 0.357 \\
\hline $\mathrm{L}_{P=175}$ & -3.958 & 0.347 \\
\hline Simple & -11.408 & 1 \\
\hline
\end{tabular}

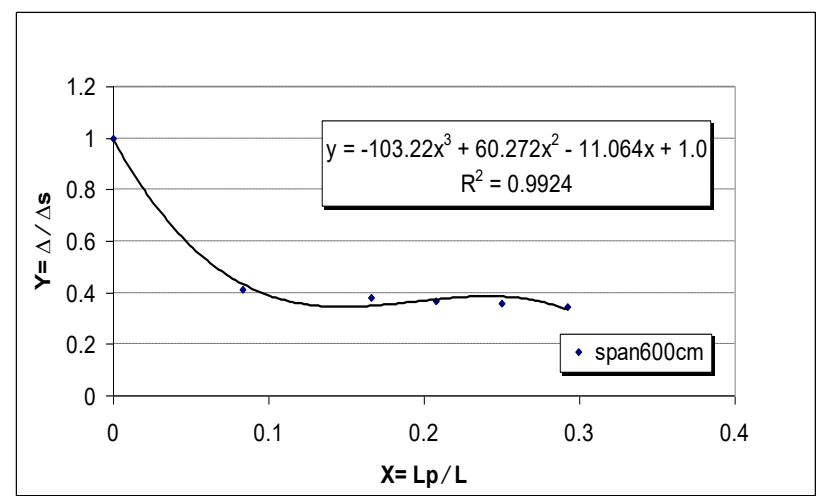

Fig . (14) Relation between $\Delta / \Delta$ s and $L_{p} / L$ for Span $600 \mathrm{~cm}$

From Fig.(14) the following equation can be obtained.

$$
\begin{aligned}
\Delta / \Delta \mathrm{s}= & -103.22\left(\mathrm{~L}_{p} / \mathrm{L}\right)^{3}+60.272\left(\mathrm{~L}_{p} / \mathrm{L}\right)^{2} \\
& -11.064\left(\mathrm{~L}_{p} / \mathrm{L}\right)+1.0 \ldots \ldots \ldots \ldots . .
\end{aligned}
$$

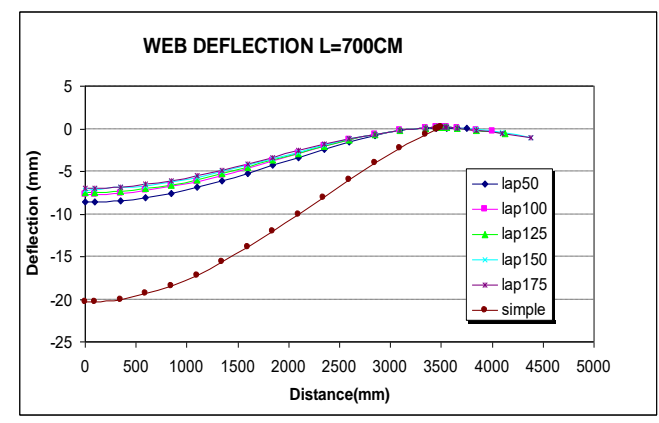

Fig • (15) Deflection along centerline of web for span $700 \mathrm{~cm}$

Table (6): Deflection at mid-span for span $700 \mathrm{~cm}$

\begin{tabular}{|c|c|c|}
\hline \multirow{2}{*}{$\begin{array}{c}\text { Lap length } \\
(\mathrm{cm})\end{array}$} & \multicolumn{2}{|c|}{ Deflection at mid span } \\
\cline { 2 - 3 } & Deflection(mm) & Ratio \\
\hline $\mathrm{L}_{P}=50$ & -8.576 & 0.421 \\
\hline $\mathrm{L}_{P=100}$ & -7.709 & 0.378 \\
\hline $\mathrm{L}_{P}=125$ & -7.486 & 0.367 \\
\hline $\mathrm{L}_{P}=150$ & -7.17 & 0.352 \\
\hline $\mathrm{L}_{P}=175$ & -6.95 & 0.341 \\
\hline Simple & -20.36 & 1 \\
\hline
\end{tabular}

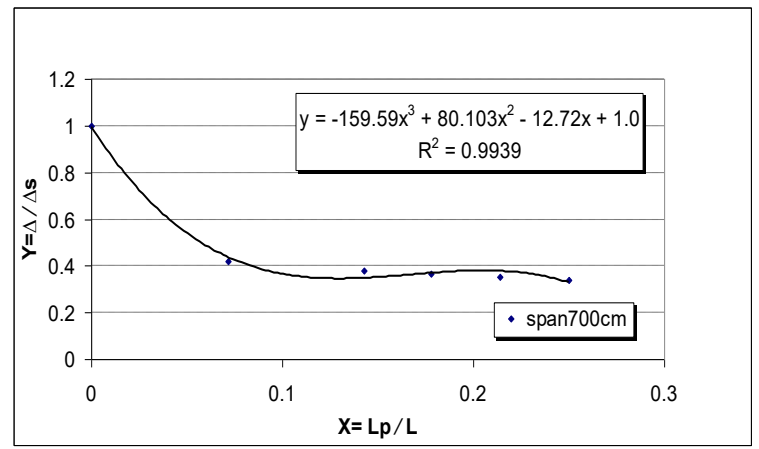

Fig. (16) Relation between $\Delta / \Delta \mathrm{s}$ and $\mathrm{I}_{p} / \mathrm{l}$ for span $700 \mathrm{~cm}$

From Fig.(16) the following equation can be obtained. 


$$
\begin{aligned}
& \Delta / \Delta=-159.59\left(\mathrm{~L}_{p} / \mathrm{L}\right)^{3}+80.103\left(\mathrm{~L}_{p} / \mathrm{L}\right)^{2} \\
& -12.72\left(\mathrm{~L}_{p} / \mathrm{L}\right)+1.0
\end{aligned}
$$

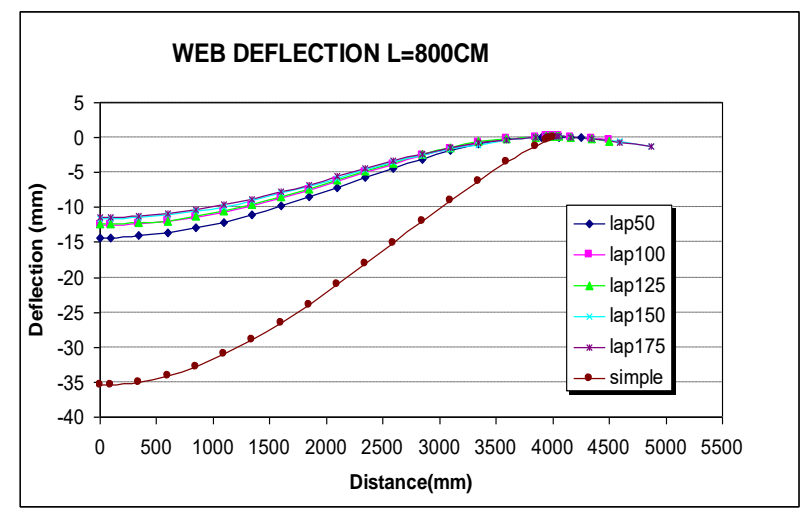

Fig - (17) Deflection along centerline of web for span $800 \mathrm{~cm}$

Table (7): Deflection at mid-span for span $800 \mathrm{~cm}$

\begin{tabular}{|c|c|c|}
\hline \multirow{2}{*}{$\begin{array}{c}\text { Lap length } \\
(\mathrm{cm})\end{array}$} & \multicolumn{2}{|c|}{ Deflection at mid span } \\
\cline { 2 - 3 } & Deflection(mm) & Ratio \\
\hline $\mathrm{L}_{P=50}$ & -14.314 & 0.405 \\
\hline $\mathrm{L}_{P=100}$ & -12.599 & 0.356 \\
\hline $\mathrm{L}_{P}=125$ & -12.315 & 0.348 \\
\hline $\mathrm{L}_{P=150}$ & -11.749 & 0.332 \\
\hline $\mathrm{L}_{P=175}$ & -11.47 & 0.324 \\
\hline Simple & -35.39 & 1 \\
\hline
\end{tabular}

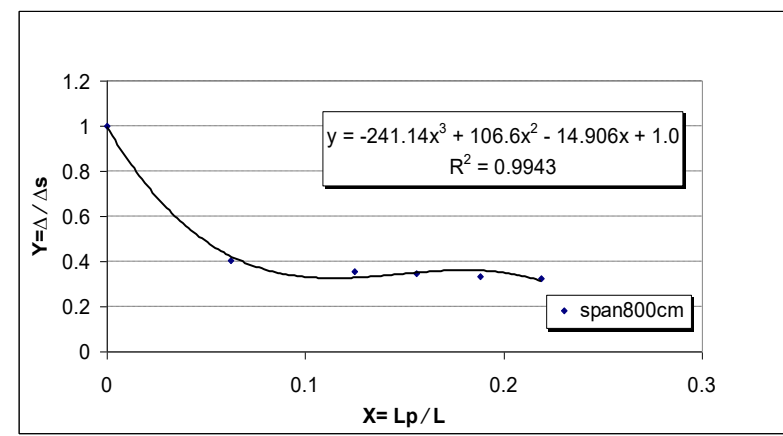

Fig. (18) Relation between $\Delta / \Delta \mathrm{s}$ and $\mathrm{L}_{p} / \mathrm{L}$ for span $800 \mathrm{~cm}$

From Fig.(18) the following equation can be obtained.

$$
\begin{aligned}
& \Delta / \Delta \mathrm{s}=-241.14\left(\mathrm{~L}_{p} / \mathrm{L}\right)^{3}+106.6\left(\mathrm{~L}_{p} / \mathrm{L}\right)^{2} \\
& -14.906\left(\mathrm{~L}_{p} / \mathrm{L}\right)+1.0
\end{aligned}
$$

From the previous equations (1), (2), (3) and (4) we can get a general empirical equation for deflection of bolted lapped purlin with respect to simple beam deflection by using curve fitting as follow:

$$
\begin{array}{r}
\Delta / \Delta \mathrm{s}=\mathrm{A}\left(\mathrm{L}_{p} / \mathrm{L}\right)^{3}+\mathrm{B}\left(\mathrm{L}_{p} / \mathrm{L}\right)^{2}+\mathrm{C}\left(\mathrm{L}_{p} / \mathrm{L}\right) \\
+1.0 \quad \ldots \ldots \ldots \ldots \ldots \ldots \ldots \ldots \ldots \ldots \ldots \ldots \ldots \ldots \ldots \ldots \ldots
\end{array}
$$

The constants $\mathrm{A}, \mathrm{B}$ and $\mathrm{C}$ are equal to respectively:

$$
\begin{aligned}
\mathrm{A}= & -2.76(\mathrm{~L})^{3}+45.34(\mathrm{~L})^{2} \\
& -295.47(\mathrm{~L})+633.24 \\
\mathrm{~B}= & 1.37(\mathrm{~L})^{3}-25.46(\mathrm{~L})^{2} \\
& +176.69(\mathrm{~L})-379.46 \\
\mathrm{C}= & -0.206(\mathrm{~L})^{3}+4.05(\mathrm{~L})^{2} \\
& -28.23(\mathrm{~L})+56.83
\end{aligned}
$$

Where:

$\Delta=$ max-deflection for lapped purlin, $\mathrm{mm}$

$\Delta s=$ max-deflection for simple purlin, $\mathrm{mm}$

$\mathrm{L}_{p}=$ lap length, $\mathrm{m}$

$\mathrm{L}=$ span of purlin , $\mathrm{m}$

Table (8) show the deflection values that obtained from the study and that values from general empirical equation. It is to be noted that the ratio given in this table is the ratio between the deflection values from empirical equation to that from F.E.M results. From the table we find that the ratio is ranging from $0.906 \%$ to $1.058 \%$ so that the general empirical equation can be used 
to predict the deflection value to this case with good results.

Table (8): Deflection values of F.E.M and Empirical General Equation

\begin{tabular}{|c|c|c|c|c|c|c|}
\hline \multirow[t]{2}{*}{ SECTION } & \multirow[t]{2}{*}{$\begin{array}{l}\text { SPAN } \\
(\mathrm{cm})\end{array}$} & \multirow{2}{*}{\begin{tabular}{l}
\multicolumn{1}{c}{ LAP } \\
LENGTH \\
$(\mathrm{cm})$
\end{tabular}} & \multicolumn{2}{|c|}{$\begin{array}{c}\text { BOLTED } \\
\text { END F.E.M }\end{array}$} & \multirow{2}{*}{$\begin{array}{c}\begin{array}{c}\text { GENERAL } \\
\text { EQUATION }\end{array} \\
\Delta / \Delta \mathbf{s}\end{array}$} & \multirow[b]{2}{*}{ RATIO } \\
\hline & & & DEFL & $\Delta / \Delta s$ & & \\
\hline \multirow{24}{*}{$200 \mathrm{Z} 20$} & \multirow{6}{*}{$\mathrm{L}=\mathbf{5 0 0}$} & $L_{p}=50$ & -2.453 & 0.444 & 0.459 & 1.033 \\
\hline & & $\mathrm{L}_{\mathrm{p}}=100$ & -2.186 & 0.395 & 0.365 & 0.925 \\
\hline & & $\mathrm{L}_{\mathrm{p}}=125$ & -2.091 & 0.378 & 0.381 & 1.007 \\
\hline & & $\mathrm{L}_{\mathrm{p}}=\mathbf{1 5 0}$ & -2.027 & 0.366 & 0.385 & 1.045 \\
\hline & & $L_{p}=175$ & -1.967 & 0.354 & 0.328 & 0.929 \\
\hline & & Simple & -5.528 & 1 & 1 & 1 \\
\hline & \multirow{6}{*}{$L=600$} & $L p=50$ & -4.771 & 0.413 & 0.433 & 1.047 \\
\hline & & $\mathrm{L}_{\mathrm{p}}=100$ & -4.357 & 0.382 & 0.346 & 0.906 \\
\hline & & $L_{p}=125$ & -4.191 & 0.367 & 0.369 & 1.007 \\
\hline & & $\mathrm{L}_{\mathrm{p}}=150$ & -4.075 & 0.357 & 0.378 & 1.058 \\
\hline & & $\mathrm{Lp}=175$ & -3.958 & 0.347 & 0.326 & 0.941 \\
\hline & & Simple & -11.408 & 1 & 1 & 1 \\
\hline & \multirow{6}{*}{$L=700$} & $\mathrm{Lp}=\mathbf{5 0}$ & -8.576 & 0.421 & 0.437 & 1.039 \\
\hline & & $\mathrm{L}_{\mathrm{p}}=100$ & -7.709 & 0.378 & 0.345 & 0.913 \\
\hline & & $\mathrm{Lp}=125$ & -7.486 & 0.367 & 0.364 & 0.993 \\
\hline & & $\mathrm{L}_{\mathrm{p}}=150$ & -7.17 & 0.352 & 0.369 & 1.049 \\
\hline & & $\mathrm{Lp}=175$ & -6.95 & 0.341 & 0.317 & 0.929 \\
\hline & & Simple & -20.36 & 1 & 1 & 1 \\
\hline & \multirow{6}{*}{$L=800$} & $\mathrm{~L} p=\mathbf{5 0}$ & -14.314 & 0.405 & 0.421 & 1.04 \\
\hline & & $L p=100$ & -12.599 & 0.356 & 0.323 & 0.908 \\
\hline & & $\mathrm{L}_{\mathrm{p}}=125$ & -12.315 & 0.348 & 0.342 & 0.984 \\
\hline & & $\mathrm{L} p=150$ & -11.749 & 0.332 & 0.348 & 1.049 \\
\hline & & $\mathrm{L}_{\mathrm{p}}=175$ & -11.47 & 0.324 & 0.296 & 0.916 \\
\hline & & Simple & -35.39 & 1 & 1 & 1 \\
\hline
\end{tabular}

\section{CONCLUSIONS}

The deflection results of the modeled purlins for each span with variables lap length in the two cases were obtained and analyzed. This study compared the behavior of simple purlin with lapped purlin for the same span. The results for section Z200*20 .It can be concluded based on the obtained results that in the analysis of lapped purlins with bolted end lap, deflection can be computed using Eq.(5) in this paper, It should be noted that the sections are loaded through the flange, which rest directly on the interior supports, and are only braced on top flange by corrugated sheets. The empirical equations were obtained to predict the deflection of bolted end lapped purlins. The results based on these equations were compared with the F.E.M results and good agreement is achieved.

\section{REFERENCES}

[1]American Iron and Steel Institute. 1996 Edition of Specification for the Design of ColdFormed Steel Structural members. Washington, DC, USA; 1997.

[2]ABAQUS.ABAQUS Version6.8.Pawtucket (RI):ABAQUS,Inc;2006.http://www.abaqus.com

[3]Ghosn A, Sinno R.,"Load capacity of nested, laterally braced, cold-formed steel Z-section beams". J Struct Eng,1996;122(8): 968-71

[4]Ghosn A., "Deflection of Nested Cold-Formed Steel Z- Section Beams", J Struct Eng 2002;128(11): 1423-28.

[5]H.C. Ho, K.F. Chung, "Analytical prediction on deformation characteristics of lapped connections between cold-formed $\mathrm{Z}$ sections" ,Thin-Walled Struct 44; (2006):115-130.

[6]Ghosn A, Sinno R., "Governing stresses in Zpurlin lap joints", J Struct Eng ,1995; 121(12):1735-41. 